\title{
COMMENT
}

\section{Aware of what?}

'Awareness is all'. These were the words with which Mrs B. Ryder of Bristol, England, closed a letter to the editor in October's ET12. By it she meant that if foreign learners of English were made properly aware of all the 'slurred elided effects' in the spoken language (such as 'Whatcher doing?', common Southern British English for 'What are you doing?') their task of using and understanding the language would be appreciably lightened.

Others have written to $E T$ about 'language awareness' as a powerful new approach to teaching the language on all fronts, 'native' or 'foreign'. As a result, a large part of ET13 (or ET Vol. 4, No. 1, as it is also now known) is devoted to considerations of what the phrase already means to some people and might yet mean to others.

The discussion opens obliquely, with John Boyd, a freelance writer in Japan, replying to the more orthodox and traditional among 'pop grammarians', 'linguistic popes', and those who set out to protect the language from the uncouth and illiterate. Fred Parrott sustains the libertarian momentum with a report on how usages come in and are condemned, then stay on and cease to raise a single hackle. Paul Harvey looks it 'language awareness' proper, in its social and educational setting, and George Wiley describes some effects that the approach has been having on examinations in England and Wales. We would be glad to hear about more such effects, on examinations, syllabuses, institutions and the like, from other sources.

The format of our magazine-cum-journal may be new, but the intriguing mix of information about the language at large continues in the same form and richness as before. A great deal of that wealth of material and information now comes in from readers in 50 or more countries around the world, evidence that many people have made $E T$ their own, whatever its shape may be.

Tom McArthur

A call for papers: In $E T$ 's files we have cuttings/clippings from a wide range of British and North American newspapers, and a scattering of material from many other sources. If readers would care to add to our files by sending in occasional (titled and dated) materials from their local newspapers, etc., or even the odd complete sample of a specially interesting periodical, this would be a great help in widening the range of usage which we can quote in From Our Files.

The editorial policy of English Today is to provide a focus or forum for all sorts of news and opinion from around the world. The points of view of individual writers are as a consequence their own, and do not reflect the opinion of the editorial board. In addition, wherever feasible, ET leaves unchanged the orthography (normally British or American) and the usage of individual contributors, although the editorial style of the magazine itself is that of Cambridge University Press.

\begin{abstract}
(C) Cambridge University Press 1988. No contents may be reproduced by any means without the permission of Cambridge University Press.
\end{abstract}

English Today (ISSN 0266-0784) is a quarterly.

\section{UNITED KINGDOM:}

Publisher: Cambridge University Press, Edinburgh Building, Shaftesbury Road, Cambridge CB2 2RU. Telephone (0223) 312393

Subscriptions: the current annual subscription price for four issues for libraries and institutions is $£ 30$ in UK $\Sigma 33$ elsewhere; $\Sigma 15$ for individuals;

\&10 for students and the retired; airmail \&8 per year extra. Apply to

Paul Driver.

Promotion: write to Lesley Boyle, at the above address.

Advertising Sales: write to Andrew

Patterson at Rooms 484-6.

Tavistock House South, Tavistock

Square, London WC1. Telephone (01) 3887487 .

\section{USA AND CANADA:}

Publisher: Cambridge University Press, 32 East 57th Street, New York 10022. Telephone (212) 6888888 .

Subscriptions: the current annual subscription price in USA and Canada for libraries and institutions is $\$ 50$; $\$ 25$ for individuals; $\$ 17.50$ for students and the retired; Copies are air-freighted to New York to arrive with a minimum delay. Apply to Linda Huppelsberg.

Promotion: write to Harry Florentine at the above address.

Advertising Sales: write to Julie Hamburger at the above address.

Application to mail at second class postage rates pending at New York. NY and at additional mailing offices. POSTMASTER: send address changes in USA and Canada to English Today, Cambridge University Press, 32 East 57th Street, New York, NY 10022.

Letters to the Editor: write to Dr Tom McArthur, Editor, English Today, 22-23 Ventress Farm Court, Cherry Hinton Road,

Cambridge CB1 4HD, UK.

Typeset by Goodfellow \& Egan. Printed in the UK at the University Press, Cambridge. 